University of Nebraska - Lincoln

DigitalCommons@University of Nebraska - Lincoln

Nebraska Game and Parks Commission -- Staff

Research Publications

Nebraska Game and Parks Commission

8-31-2019

\title{
Neonicotinoid insecticide concentrations in agricultural wetlands and associations with aquatic invertebrate communities
}

Travis J. Schepker

Elisabeth B. Webb

Donald Tillitt

Ted LaGrange

Follow this and additional works at: https://digitalcommons.unl.edu/nebgamestaff

This Article is brought to you for free and open access by the Nebraska Game and Parks Commission at DigitalCommons@University of Nebraska - Lincoln. It has been accepted for inclusion in Nebraska Game and Parks Commission -- Staff Research Publications by an authorized administrator of DigitalCommons@University of Nebraska - Lincoln. 


\title{
Neonicotinoid insecticide concentrations in agricultural wetlands and associations with aquatic invertebrate communities
}

\author{
Travis J. Schepker ${ }^{\mathrm{a}, 1, *}$, Elisabeth B. Webb ${ }^{\mathrm{b}}$, Donald Tillitt ${ }^{\mathrm{c}}$, Ted LaGrange ${ }^{\mathrm{d}}$ \\ ${ }^{a}$ Missouri Cooperative Fish and Wildlife Research Unit, Department of Fisheries and Wildlife Sciences, University of Missouri, Columbia, MO 65211, USA \\ ${ }^{\mathrm{b}}$ U.S. Geological Survey, Missouri Cooperative Fish and Wildlife Research Unit, Department of Fisheries and Wildlife Sciences, University of Missouri, Columbia, MO \\ 65211, USA \\ ${ }^{\mathrm{c}}$ U.S. Geological Survey, Columbia Environmental Research Center, 4200 New Haven Road, Columbia, MO 65201, USA \\ ${ }^{\mathrm{d}}$ Nebraska Game and Parks Commission, 2200 N. 33rdStreet, Lincoln, NE 68503, USA
}

\section{A R T I C L E I N F O}

\section{Keywords:}

Neonicotinoid

Vegetative buffers

Wetlands

Aquatic invertebrates

\begin{abstract}
A B S T R A C T
Neonicotinoids are considered a superior insecticide for agricultural pest management, although their impacts on non-target insects is a rising concern. Aside from laboratory and mesocosm studies, limited research has been directed towards the role neonicotinoids may have in structuring aquatic invertebrate communities in field settings. Therefore, we simultaneously collected aquatic invertebrate and surface water samples from 26 wetlands within a highly modified agricultural landscape of Nebraska's Rainwater Basin during spring 2015. Water samples were tested for six different neonicotinoids, nutrients, and physical properties. Trace levels of clothianidin and imidacloprid were the only neonicotinoids detected, occurring in $85 \%$ and $15 \%$, respectively, of wetlands sampled. All measurements for clothianidin and imidacloprid were below chronic toxicity benchmarks set by the United States Environmental Protection Agency. Neonicotinoid concentrations were significantly lower $\left(\mathrm{W}_{26,0.05}=42.5\right)$ at wetlands with vegetative buffer strips $>50 \mathrm{~m}$ wide compared to wetlands with vegetative buffers strips $<50 \mathrm{~m}$. Although neonicotinoids were below benchmark concentrations proposed by government regulations, a significant negative association between neonicotinoid concentrations and aquatic invertebrate biomass was observed across all wetlands studied (Parameter Estimate $=-0.031 ; \mathrm{SE}=0.014$ ).
\end{abstract}

\section{Introduction}

Persistence of healthy and sustainable aquatic invertebrate communities depends in large part on the abiotic and biotic characteristics of aquatic systems, especially in wetlands (Cairns and Pratt, 1993; Davis and Bidwell, 2008; Riens et al., 2013). Although aquatic invertebrates are not generally a major focus of wetland management practices, they provide an essential link for energy flow between primary producers and most vertebrate wetland-dependent taxa, including fish, amphibians, and waterbirds (Covich et al., 1999; Boix and Batzer, 2016). In addition to channeling energy into higher trophic levels, benthic invertebrates provide essential ecosystem functions by accelerating decomposition rates for organic detrital matter (Covich et al., 1999). These ecosystem processes redistribute bound nutrients within the water column, facilitating absorption by bacteria, fungi, algae, and aquatic angiosperms (Wallace and Webster, 1996; Covich et al., 1999; Kalff, 2002). The broad range of sensitivity to contaminants and sedimentation exhibited by aquatic invertebrate communityis means that they also serve as excellent bioindicators for assessing wetland ecosystem health (Cairns and Pratt, 1993; Spieles and Mitsch, 2000; Riens et al., 2013).

Synthetic insecticides are components of agricultural runoff from cropped fields and have been repeatedly shown to negatively impact aquatic invertebrate communities in numerous mesocosm and semifield studies (Cuffney et al., 2000; Miles et al., 2017; Pereira et al., 2017). Neonicotinoids are currently among the most widely used class of synthetic insecticides and are projected to increase in agricultural application during the coming years (Sparks, 2013; USGS National Synthesis Project, 2017). Rapid increase in neonicotinoid use has been attributed to versatility of application and relatively low risk to nontarget vertebrate organisms such as mammals, birds, and fish (Jeschke et al., 2010). The intended targets for most neonicotinoid applications include aphids and other agricultural pest insects; however, concerns have developed that neonicotinoids also affect non-target invertebrate

\footnotetext{
* Corresponding Author at: United States Army Corps of Engineers, 100 Arsenal Street, Saint Louis, Missouri 63118, USA.

E-mail address: Travis.J.Schepker@usace.army.mil (T.J. Schepker).

${ }^{1}$ Present Address: United States Army Corps of Engineers, 100 Arsenal Street, Saint Louis, MO 63118, USA.
} 
taxa, and wildlife dependent on these invertebrate taxa as a food source (Hallmann et al., 2014; Sánchez-Bayo et al., 2016; Main et al., 2018). In recent years, neonicotinoids have been detected in surface waters adjacent to agricultural areas, in some studies at or above concentrations of acute and chronic exposure thresholds for many common aquatic invertebrate species (Van Dijk et al., 2013; Hladik et al., 2014; Main et al., 2014; Morrissey et al., 2015; Evelsizer and Skopec, 2018; Cavallaro et al., 2019).

In response to elevated concentrations observed during field surveys, laboratory and mesocosm studies have assessed potential threats to a magnitude of aquatic invertebrate taxa (reviewed in Anderson et al., 2015; Sánchez-Bayo et al., 2016). Collectively, laboratory and mesocosm studies indicate a wide-range of acute, chronic, and sub-lethal toxicity endpoints for a variety of taxa (reviewed in Morrissey et al., 2015; Cavallaro et al., 2017). Indeed, recent mesocosm studies has been critical for developing guidelines for registration of systemic insecticides and aquatic benchmark criteria (EPA, 2019). In addition, several studies have evaluated associations between aquatic community responses and exposure to neonicotinoids (Goulson, 2013; Morrissey et al., 2015; Smit et al., 2015); however, much of the evidence has come from mesocosm studies, thus a simultaneous assessment of aquatic invertebrate communities and neonicotinoid concentrations in a field setting was needed (Main et al., 2018). Such a study could simultaneously monitor aquatic invertebrate communities, neonicotinoid concentrations, and other relevant environmental attributes (Evelsizer and Skopec, 2018). Given the highly sporadic and unpredictable nature of aquatic invertebrate communities, developing meaningful toxicity endpoints from field studies may be unrealistic. Rather, field studies could provide an opportunity to compare aquatic invertebrate community structure with suggested aquatic threshold criteria.

Approximately $75 \%$ of the historic land cover in Nebraska's Rainwater Basin (RWB) has been converted to agricultural land use, including corn (Zea mays), soybean (Glycine max), and other agricultural management regimes, which corresponds to at a minimum, $75 \%$ of the wetlands in the region considered to be impacted by agricultural runoff (Fig. 1; USGS National Synthesis Project 2017). Wetlands in the RWB are classified as playas, which are ephemeral, closed basin systems whose hydrology is primarily driven by precipitation and surface runoff (Smith, 2003). Most playas do not receive ground water inflow; therefore, the chemical, physical, and biological integrity of playas is influenced predominately by surrounding land use (Belden et al., 2012). Consequently, water-soluble contaminants and sediments transported into playas are more likely to persist as water subsides and accumulate between inundation events (Belden et al., 2012). Accumulation of neonicotinoids in RWB wetlands is potentially a matter of environmental concern given the chemicals half-lives range from 200 to $>1000$ days in soil, and as many as 420 days in water (Rexrode et al., 2003; Goulson, 2013; Morrissey et al., 2015).

Runoff and overflow from agricultural fields within a watershed drains into some playas directly (point source) via drainage ditches and culverts, whereas other wetlands receive nonpoint source runoff after it has been filtered through buffers of native-herbaceous vegetation (Anderson et al., 2013; Rainwater Basin Joint Venture, 2013). Riens et al. (2013) reported that vegetative wetland buffers could intercept sediments bound with nitrogen, phosphorous, and atrazine, thereby improving water quality within a wetland. The Canadian providence of Prince Edward Island passed legislation in 2000 that required wetlands contiguous to agricultural fields be buffered with $10 \mathrm{~m}$ to $30 \mathrm{~m}$ vegetation strips (Environmental Protection Act, 2005). Dunn et al. (2011) assessed the effectiveness of the Prince Edward Island initiative and found that $10 \mathrm{~m}$ and $30 \mathrm{~m}$ buffers removed $52 \%$ and $78 \%$ of the pesticides analyzed, respectively; however, neonicotinoids were not evaluated. Currently, limited information is available on the potential of vegetative buffers for mitigating neonicotinoid concentrations in wetlands (Main et al., 2017).

Although numerous studies have identified the impacts of neonicotinoids on aquatic invertebrates in controlled laboratory and mesocosm studies (Song et al., 1997; Beketov and Liess, 2008; Beketov et al., 2008; Miles et al., 2017), few studies have evaluated the relationship between neonicotinoids and invertebrate communities under field conditions (Anderson et al., 2015; Cavallaro et al., 2019). Therefore, the primary objectives of this study were to: (1) quantify aquatic concentrations of neonicotinoid insecticides at playa wetlands in the RWB, (2) compare neonicotinoid concentrations in wetlands with and without vegetative buffers, and (3) determine the association of neonicotinoid concentrations, as well as other environmental variables, with aquatic invertebrate communities.

\section{Materials and methods}

\subsection{Study area and experimental design}

Nebraska's RWB spans across 21 counties in south-central Nebraska, located south of the Platte River (Fig. 1). Playas in the RWB are characterized as small depressional wetlands, lined with a relatively impermeable clay layer positioned at the low spot of a closed basin

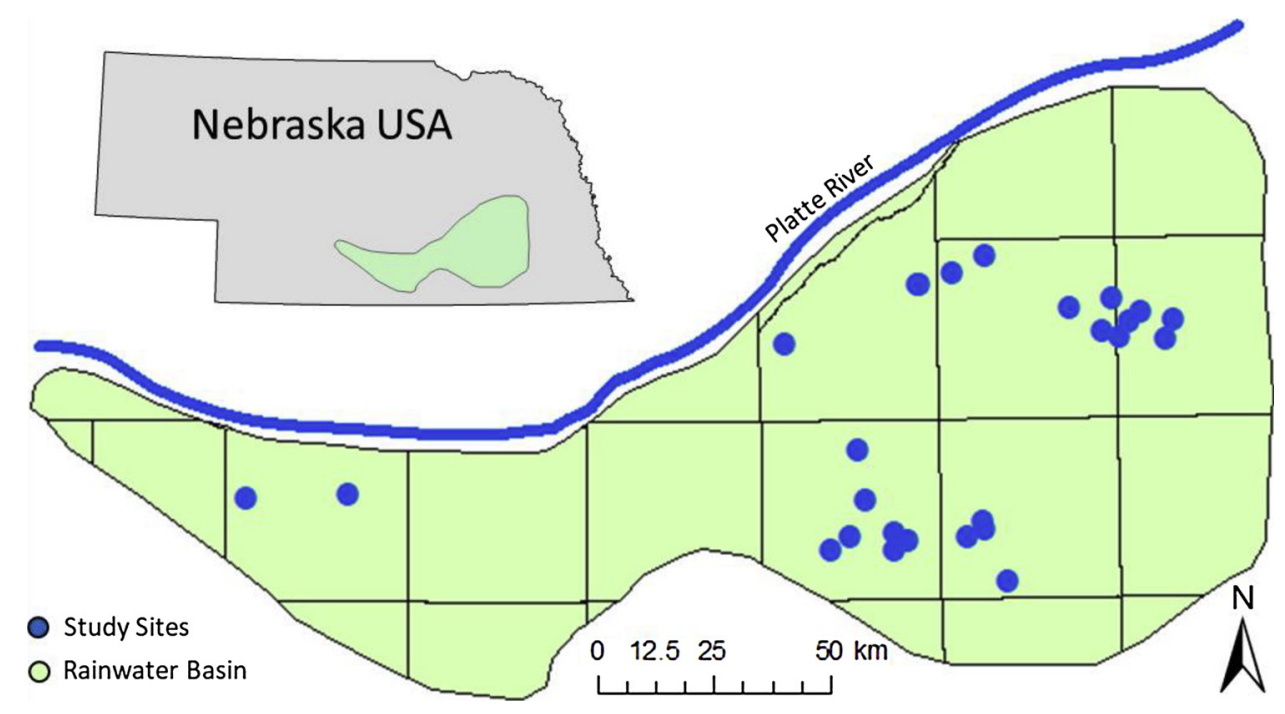

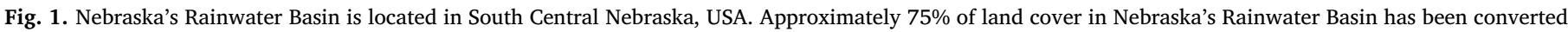
from mixed prairie grassland to agricultural production. Accordingly, $75 \%$ of the region's wetlands receive contaminated runoff from upland crop fields. 
watershed (Smith, 2003). Most RWB playas are seasonally or ephemerally inundated, with historic hydrologic processes driven by surface runoff following intense precipitation and accumulated snowmelt (Bolen et al., 1989; Smith, 2003; LaGrange, 2005). Historically the RWB contained $>11,000$ playas and approximately 80,000 ha of wetlands (McMurtrey et al., 1972). However, drainage ditches, concentration pits, sedimentation, and agricultural expansion within the region resulted in a 90\% reduction in overall wetland area in the region (Raines, 1990; LaGrange, 2005). Nevertheless, playas in the RWB provide habitat to wetland-dependent invertebrates, amphibians, and waterbirds, and deliver water quality services in the form of flood storage, nutrient retention, and sediment trapping (Smith, 2003; LaGrange, 2005; Webb et al., 2010).

This study was part of a comprehensive project that assessed habitat selection of waterfowl during spring migration in the RWB. The RWB serves as a critical staging area to $\sim 7$ million dabbling ducks, including $50 \%$ of North America's mid-continent mallard (Anas platyrhynchos) population, and $30 \%$ of North America's total Northern pintail (A. acuta) population (Rainwater Basin Joint Venture 2013). During spring, waterfowl depend on aquatic invertebrates as a food resource to accumulate the energy and protein needed to complete migration and initiate egg production (Devries, 2008; Tidwell et al., 2013). If demands for quality food resources are not met, waterfowl may arrive at breeding grounds in poorer body condition, and consequently be less likely to achieve reproductive success (Devries, 2008). Given the importance of aquatic invertebrate acquisition at mid-latitude stopover sites and subsequent effects on recruitment, the primary objective of the overall project was to improve understanding of factors influencing waterfowl food resource availability in wetlands and the relationship to habitat use by spring-migrating waterfowl.

The timeframe of our study was selected to coincide with the timing of spring waterfowl migration in the RWB. During 2015, waterfowl arrived to the RWB during the first week of March, with peak migration occurring during the first week of April, and migration concluding in late April. Consequently, neonicotinoid concentrations reflect preplanting conditions. Regardless, this study was primarily interested in habitat factors that influenced aquatic invertebrate communities during spring waterfowl migration. We assessed habitat conditions at public wetlands, private wetlands enrolled in the Wetlands Reserve Program (WRP) that have had some level of restoration, and private wetlands managed for agriculture (row crop and grazing).

\subsection{Study site selection}

During spring 2015, we stratified potential study sites in the RWB by county, identified the six counties containing the greatest number of inundated wetlands (with inundated area $>1$ ha), and randomly selected individual wetlands within those counties (Tapp and Webb, 2015; Schepker et al., 2019). We selected 12 public and 14 private wetlands throughout Phelps, Clay, Fillmore, York, Seward, and Hamilton counties. Precipitation preceding and during spring 2015 was minimal, and consequently, inundated wetlands were relatively scarce (National Oceanic and Atmospheric Administration, 2017; Supplementary Table S1). Four of the selected private sites became dry halfway through the study and were excluded from the aquatic invertebrate component of our analysis. We obtained information from land managers on management activities that occurred on study sites during the previous three years. Specific management techniques included grazing, mowing/disking, prescribed burning, and undisturbed.

\subsection{Measured local variables}

We collected 48 composite water samples during March $(n=26)$ and April $(n=22)$ from our 26 study sites prior to spring planting. We obtained a composite neonicotinoid sample from each wetland by collecting a $\sim 250 \mathrm{ml}$ grab sample from below the water surface at four random locations within the inundated portion of the wetland. Samples were stored in containers 1-liter amber glass bottles furnished by the contracted laboratory, preserved on ice $\left(<4^{\circ} \mathrm{C}\right)$, and submitted/accepted under chain of custody documentation within $96 \mathrm{~h}$ of being collected. Neonicotinoids evaluated in this study were those commonly used for crop production in the RWB, which included acetamiprid, clothianidin, dinotefuran, imidacloprid, thiacloprid, and thiamethoxam (USGS National Synthesis Project, 2017). Neonicotinoid concentrations were quantified at the Water Science Laboratory at the University of Nebraska-Lincoln using solid phase extraction and liquid chromatography-tandem mass spectrometry (Satkowski et al., 2018; see detail methods in Supplementary Tables S2-S4). QA/QC included laboratory reagent and fortified blanks, as well as field duplicate samples for each sampling period. Concentration-based limit of quantitation (LOQ) were $0.002 \mu \mathrm{g} \mathrm{L}^{-1}$ for the six neonicotinoids analyzed. For the purposes of this study, measurements that did not exceed the LOQ were treated as $0.000 \mu \mathrm{L} \mathrm{L}^{-1}$. Composite chlorophyll_ a, total nitrogen, and total phosphorous samples were collected from four random locations at each wetland, stored in preserved and unpreserved bottles furnished by the contracted laboratory, stored on ice $\left(>4^{\circ} \mathrm{C}\right)$, and submitted/accepted under chain of custody documentation. Chlorophyll_ $a$, total nitrogen, and total phosphorous were analyzed by the Limnology Laboratory at the University of Missouri-Columbia (Sartory and Grobbelaar, 1984; Crumpton et al., 1992; Eaton et al., 1995). Additional water quality parameters that have been shown to influence aquatic invertebrate communities included in this study were conductivity, pH, turbidity, total dissolved solids (Bilotta and Brazier, 2008; Riens et al., 2013; Cavallaro et al., 2019). Those parameters were measured at study wetlands bi-monthly using a handheld YSI multiparameter system following the manufacturer's specifications for deployment and calibrations. Emergent vegetative cover has previously been associated with wetland aquatic invertebrate community structure, thus integrated into this study (Murkin et al., 1982; De Szalay and Resh, 2000; Davis and Bidwell, 2008). Vegetation was measured as the percentage of vegetative cover within a square meter quadrat adjacent to invertebrate sample location and was assessed bi-monthly.

\subsection{Measured landscape variables}

Proximity to nearest wetland may influence aquatic invertebrate species diversity and recolonization potential at ephemeral wetlands following natural drought cycles (Euliss et al., 1999; Delettre and Morvin, 2000; Gledhill et al., 2008). In addition to emergence from local cysts and eggs, invertebrates also repopulate ephemeral systems from external sources by wind, in the digestive tracts of birds, and by adhering to larger vertebrate and invertebrate fauna (Proctor, 1964; Pennak, 1989; Euliss and Mushet, 1999). To account for this potential association, we established three explanatory variables describing landscape configuration: (1) number of inundated wetlands $>1$ ha area within $2.5 \mathrm{~km}$ of a study site, (2) total inundated wetland area within $2.5 \mathrm{~km}$ of a study site, and (3) distance from study wetland perimeter to the nearest cropped field. We used sets of aerial imagery from multiple dates to define and measure change of wetland inundation for the surrounding landscape during the entirety of our study. We downloaded Landsat 8 Operational Land Imager and Thermal Infrared Sensor data sets from www.earthexplorere.usgs.gov using the U.S. Geological Survey Bulk Download Application. We downloaded imagery from the Landsat World Reference System during dates from February 24 - April 13 (Schepker, 2017). Images were visually inspected and considered unusable when atmospheric disturbance occurred (Hansen and Loveland, 2012). Supplemental imagery was obtained from multispectral orthophotography collected by aircraft during the week of March 8, 2015 (Rainwater Basin Joint Venture annual spring habitat survey). For weeks when no imagery was available, wetland area was extrapolated using the mean rate of change from the prior two weeks. Satellite and multispectral orthophotography were 
processed in ArcMap 10.3 (ESRI, 2015) using ModelBuilder to develop, edit, and manage model workflow. Methods for processing imagery in ArcMap 10.3 and validation techniques from this study were described in greater detail in Schepker (2017).

\subsection{Invertebrate collection and processing}

We assessed benthic and nektonic aquatic invertebrate communities in alternating weeks from 22 February through 18 April 2015. At each wetland, we established 3-5 (dependent on wetland area) randomly located $3 \mathrm{~m} \times 3 \mathrm{~m}$ sample plots at water depths $<30 \mathrm{~cm}$ and where vegetative cover was $<50 \%$ (Schepker et al., 2019). Within each plot, we collected two nektonic samples using a $500 \mu \mathrm{m}$ rectangular sweep net (Tapp and Webb, 2015). The net was lowered vertically into the water column, pressed firmly against the substrate, and moved through the water column for a distance of $1.1 \mathrm{~m}\left(0.5 \mathrm{~m}^{2}\right.$; Klemm et al., 1990; Davis and Bidwell, 2008). A total of four passes were made with the sweep net. We also collected two benthic invertebrate samples using a $10 \mathrm{~cm}$ diameter $\times 5 \mathrm{~cm}$ deep benthic core sampler in an undisturbed area adjacent to the corresponding nektonic sampling location (Swanson, 1983). Benthic and nektonic invertebrate samples were preserved in $70 \%$ ethanol to prevent deterioration (Murkin and Kadlec, 1986) and transported to the University of Missouri for processing.

Invertebrate samples were stained with rose bengal for $24 \mathrm{~h}$ prior to processing to enhance efficiency of sorting and identification (Sherfy et al., 2000). We rinsed invertebrate samples through a series of two graduated sieves $(\# 50[500 \mu \mathrm{m}]$ and $\# 10[250 \mu \mathrm{m}])$ to remove small clay particles and partition remaining materials into coarse and fine samples (Schepker et al., 2019). We used a Folsom wheel sample splitter (Aquatic Research Instruments) to subsample ( $1 / 4$ volumes) material retained by the $250 \mu \mathrm{m}$ and $500 \mu \mathrm{m}$ sieves (Whiting et al., 2011). Aquatic invertebrates were removed from remaining debris, adults and larvae were identified to the lowest taxonomic level practical, measured to the nearest millimeter, and catalogued (Schepker et al., 2019). Biomass estimates for individual taxa were obtained using regressions of dry length-mass (Duffy and LaBar, 1994; Benke et al., 1999; Schepker et al., 2019). When a length-mass regression was not available for specific taxa or species, we used estimates from taxonomically-similar species observed in comparable habitats (Benke and Huryn, 2006). Biomass estimates were pooled and averaged for all taxa collected at a wetland for each sampling event and converted to biomass density estimates ( $\mathrm{g}$ dry mass $\mathrm{m}^{-2}$ ). Secondary production was then calculated using the Production: Biomass (P:B) method for each taxonomic group (Equation 1; Benke, 1984; Duffy and LaBar, 1994) from published P:B values (Waters, 1977; Duffy and LaBar, 1994; Stagliano and Whiles, 2002; Benke and Huryn, 2006; Whiting et al., 2011; Butkas, 2011).

Secondary Production $2=$ biomass $2 \times \frac{\text { Production }_{1}}{\text { biomass }_{1}}$

where:

Production $_{1}$ is the annual production value from a previous study.

Biomass $_{1}$ is the total biomass from a previous study.

Biomass $_{2}$ is the biomass from the current study.

Lastly, we used the Shannon Diversity Index to account for the abundance and evenness of invertebrates present at each wetland (Clarke and Warwick, 2001). Calculations for Shannon's Diversity Index were performed in R Studio using the VEGAN package (Oksanen et al., 2017).

\subsection{Statistical analysis}

\subsubsection{Quantitative evaluation of neonicotinoid concentrations and toxicity} benchmarks

We used a paired $t$-test to identify differences in total neonicotinoid concentrations for the 22 wetlands inundated during both sampling periods. Neonicotinoid toxicity benchmarks for aquatic invertebrates used for comparison were derived from the United States Environmental Protection Agency's Aquatic Life Benchmarks for Freshwater Species (EPA, 2019). We conducted a one-sample $t$-test for each neonicotinoid benchmark to determine if concentrations measured at wetlands exceeded chronic threshold concentrations recommended for aquatic life. Given the time of year water samples were collected (approximately 30-60 days prior to spring planting), aquatic neonicotinoid concentrations observed in this study likely represented chronic conditions, thus acute benchmark concentrations were not evaluated.

\subsubsection{Neonicotinoid concentrations in buffered $v$ s non-buffered wetlands}

We used multispectral orthophotography imagery collected by aircraft during the week of March 8, 2015 to identify buffered and nonbuffered wetlands. We defined a wetland as buffered when the entire perimeter was surrounded by $>50 \mathrm{~m}$ of vegetation other than row crops. We classified a wetland as non-buffered when $<50 \mathrm{~m}$ of vegetation other than row crops was present between the wetted edge of a wetland and a cropped field. A minimum $50 \mathrm{~m}$ vegetative buffer width was identified as maximizing contaminant removal from runoff entering playa watersheds (Johnson, 2011) and was thus established as a goal by the Rainwater Basin Joint Venture (2013) for wetland restoration and enhancement projects. We also classified sites with predominant drainage features leading from a cropped fields into a wetland as non-buffered (Riens et al., 2013). Total neonicotinoid concentrations in buffered and non-buffered wetlands did not follow normal distributions, and sample size was small, thus a Wilcoxon rank sum test with continuity correction was conducted to compare total neonicotinoid concentrations at buffered and non-buffered wetlands (Quinn et al., 2002).

\subsubsection{Associations between neonicotinoids and aquatic invertebrate community structure}

We developed a set of a priori candidate models to explain nektonic and benthic invertebrate diversity, biomass $\left(\mathrm{g} \mathrm{m}^{-2}\right)$, and invertebrate community production based on ecologically reasonable scenarios (Tables 1 \& 2 ; Gleason et al., 2003; Riens et al., 2013; Van Dijk et al., 2013). We used an information theoretic approach to evaluate $a$ priori models for explaining local and landscape response variables (Burnham and Anderson, 2002) using linear mixed model procedures, Akaike's Information Criterion (AICc) values, and model weights (AICmodavg; Mazerolle, 2016). Biomass and secondary production did not exhibit normal distributions, and were normalized with a Yeo-Johnson Power Transformation (Yeo and Johnson, 2000). To prevent heteroscedasticity in fitted residuals, we scaled and centered all independent variables on zero (Gelman, 2008). Pearson's r-correlation indices were used to test for multicollinearity between independent variables in candidate models (Dormann et al., 2013). When evaluating response variables for nektonic communities, we included water depth in all a priori models, given the strong relationship water depth had with all response variables for this study. We analyzed a priori models for nektonic and benthic communities separately because of differences in sampling device and predicted community structure (Tapp and Webb, 2015). For each response variable, we fit models using maximum likelihood estimations, and calculated output statistics including second order AICc values and AICmodavg (Mazerolle, 2016). All models within two $\triangle$ AICc values of the most parsimonious model were considered competitive and included in our set of competing models (Richards, 2005). For each competing model, we performed a Shapiro-Wilk test on the distribution of fitted residuals for normality, and discarded models when the resulting $\mathrm{p}$-value was $<0.05$. We used a coefficient of determination $\left(\mathrm{R}^{2}\right)$ adjusted for the number of predictors to measure the goodness of fit for each model selected. Models with an adjusted $\mathrm{R}^{2}<0.10$ were removed, as those models did not explain a meaningful percentage of variability for response variables (Stephens et al., 2005). Finally, we calculated the natural average for each parameter estimate observed in the remaining 
Table 1

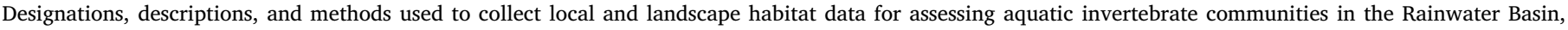
spring 2015.

\begin{tabular}{|c|c|c|}
\hline Variable & Description & Methods \\
\hline Veg & $\%$ emergent vegetation & Percentage of wetland area where emergent vegetation occurred opposed to open water. \\
\hline Depth & Mean water depth & Water depth $(\mathrm{cm})$ was measured bi-monthly by recording depths at $12-16$ random locations and averaged for the wetland. \\
\hline Neonic & Neonicotinoids & Neonicotinoid $\left(\mu \mathrm{g} \mathrm{L}^{-1}\right)$ was measured and averaged from monthly composite grab samples. \\
\hline NeonicMax & Neonicotinoids Max & Maximum neonicotinoid concentration observed between the two sample periods. \\
\hline TN & Nitrogen & Total Nitrogen (mg L $\mathrm{L}^{-1}$ ) was measured and averaged from monthly composite grab samples. \\
\hline TP & Phosphorus & Total Phosphorus ( $\mathrm{mg} \mathrm{L}^{-1}$ ) was measured and averaged from monthly composite grab samples. \\
\hline Turb & Turbidity & Turbidity (NTU) was measured and averaged from monthly composite grab samples. \\
\hline $\mathrm{pH}$ & $\mathrm{pH}$ & pH was measured bi-monthly at $12-16$ locations in each wetland and averaged. \\
\hline Cond & Conductivity & Conductivity $\left(\mu \mathrm{S} \mathrm{cm}^{-1}\right)$ was measured bi-monthly at 12-16 locations in each wetland and averaged. \\
\hline TDS & Total Dissolved Solids & Total dissolved solids (mg L ${ }^{-1}$ ) were measured bi-monthly at 12-16 locations in each wetland and averaged. \\
\hline $2 \mathrm{kmDen}$ & $2.5 \mathrm{~km}$ wetland complex & $\begin{array}{l}\text { Inundated wetland density within a } 2.5 \mathrm{~km} \text { radius of a study site. Wetland density was assessed every } \sim 16 \text { days using satellite and } \\
\text { aerial imagery. }\end{array}$ \\
\hline 2kmUnits & $2.5 \mathrm{~km}$ wetland complex & $\begin{array}{l}\text { Number of inundated wetlands }>1 \text { ha in area within a } 2.5 \mathrm{~km} \text { radius of a study site. Wetland density was assessed every } \sim 16 \text { days } \\
\text { using satellite and aerial imagery. }\end{array}$ \\
\hline DistRC & Distance to Cropped Field & Distance (meters) from perimeter of wetland to the nearest cropped field. \\
\hline
\end{tabular}

Table 2

: a priori candidate models used to explain variation in benthic and nektonic invertebrate communities at wetlands in Nebraska's Rainwater Basin, spring 2015.

\begin{tabular}{|c|c|}
\hline Level & Model \\
\hline Local_Non Neonic Models & $\begin{array}{l}1+\text { Depth + Chlorophyll } a \\
1+\text { Depth + Phosphorus } \\
1+\text { Depth + Nitrogen } \\
1+\text { Depth + Turbidity } \\
1+\text { Depth + Total Dissolved Solids } \\
1+\text { Depth + Conductivity } \\
1 \text { + Depth + pH } \\
1 \text { + Depth + Vegetative Cover }\end{array}$ \\
\hline Local_Neonic Models & $\begin{array}{l}1+\text { Depth + Neonic } \\
1+\text { Depth }+ \text { Neonic Maximum Observed } \\
1+\text { Depth }+ \text { Neonic }+ \text { Chlorophyll } a \\
1+\text { Depth }+ \text { Neonic }+ \text { Phosphorus } \\
1+\text { Depth }+ \text { Neonic }+ \text { Nitrogen } \\
1+\text { Depth }+ \text { Neonic }+ \text { Turbidity } \\
1+\text { Depth }+ \text { Neonic }+ \text { Total Dissolved Solids } \\
1+\text { Depth + Neonic }+ \text { Conductivity } \\
1+\text { Depth + Neonic }+ \text { pH } \\
1+\text { Depth }+ \text { Neonic }+ \text { Vegetative Cover }\end{array}$ \\
\hline Landscape_Non Neonic Models & $\begin{array}{l}1+\text { Depth }+2 \mathrm{kmDensity} \\
1+\text { Depth }+2 \mathrm{kmUnits} \\
1+\text { Depth }+ \text { Cropped Distance }\end{array}$ \\
\hline Landscape_Neonic Models & $\begin{array}{l}1+\text { Depth }+ \text { Neonic }+2 \mathrm{kmDensity} \\
1+\text { Depth }+ \text { Neonic }+2 \mathrm{kmUnits} \\
1+\text { Depth }+ \text { Neonic }+ \text { Cropped Distance }\end{array}$ \\
\hline
\end{tabular}

*Depth was only considered when analyzing nektonic communities.

set of competing candidate models to estimate relative influence on invertebrate communities (Burnham and Anderson, 2002; Mazerolle, 2016). We used model-averaged parameter estimates and associated $95 \%$ confidence intervals to guide hypothesis testing.

\section{Results}

\subsection{Quantitative evaluation of neonicotinoid concentrations and toxicity benchmarks}

During spring 2015, trace levels of neonicotinoids were detected in water samples at $77 \%$ of wetlands $(n=26)$ in March, and $73 \%$ of wetlands $(\mathrm{n}=22)$ in April (Supplementary Tables S5 and S6). Total neonicotinoid concentrations did not differ between March $\left(\bar{x}=0.006 \mu \mathrm{L} \mathrm{L}^{-1}\right)$ and April $\left(\bar{x}=0.005 \mu \mathrm{g} \mathrm{L}^{-1}\right)\left(\mathrm{t}_{21,0.05}=-0.68\right)$. Clothianidin was the most frequently detected neonicotinoid, occurring at $85 \%$ of wetlands, while imidacloprid was only detected at $15 \%$ of wetlands. Acetamiprid, dinotefuran, thiacloprid, and thiamethoxam were not detected. Combining observations from both sampling periods $(\mathrm{n}=48)$, mean clothianidin concentration $\left(\bar{x}=0.005 \mu \mathrm{g} \mathrm{L}^{-1}\right)$ and imidacloprid concentration $\left(\bar{x}=0.001 \mu \mathrm{L} \mathrm{L}^{-1}\right)$ were a factor of 10 below US EPA benchmarks $\left(0.050 \mu \mathrm{gL}^{-1}\right.$ and $0.010 \mu \mathrm{g} \mathrm{L}^{-1}$, respectively).

\subsection{Neonicotinoid concentrations in buffered vs non-buffered wetlands}

Total neonicotinoid concentration averaged for March and April sampling periods at wetlands buffered by $>50 \mathrm{~m}$ of herbaceous vegetation $(\mathrm{n}=12)$ was $\bar{x}=0.004 \mu \mathrm{g} \mathrm{L}^{-1}\left(\right.$ median $\left.=0.004 \mu \mathrm{g} \mathrm{L}^{-1}\right)$ and ranged from below LOQ to $0.008 \mu \mathrm{g} \mathrm{L}^{-1}$ (Table 3). Mean concentration measured in samples collected from wetlands buffered by $<50 \mathrm{~m}$ of herbaceous vegetation $(\mathrm{n}=14)$ was $\bar{x}=0.007 \mu \mathrm{g} \mathrm{L}^{-1}$ (median $=0.006 \mu \mathrm{gL}^{-1}$ ) and ranged from below LOQ to $0.016 \mu \mathrm{g} \mathrm{L}^{-1}$. Total aquatic neonicotinoid concentrations were statistically greater in wetlands surrounded by $<50 \mathrm{~m}$ of herbaceous vegetation $\left(\mathrm{W}_{26}, 0.05=\right.$ 42.5; Fig. 2).

\subsection{Associations between neonicotinoid concentrations and invertebrate communities}

Copepoda, Diptera, and Odonata were the most common Orders observed in nektonic samples, accounting for $62 \%$ of the total measured biomass (Supplementary Table S7). Nektonic invertebrate diversity index ranged from 0.68 to 1.87 (mean $=1.41, \mathrm{SE}=0.07$ ) at 22 wetlands sampled during spring 2015 (Table 3). Explanatory variables in the best-fit model for explaining nektonic diversity included water depth (+) and $\mathrm{pH}(-)$, which accounted for $35 \%$ of total AICc weight (Table 4). Both explanatory variables observed in the model were significant $(\mathrm{p}>0.05)$. Subclass Hirudinea, and Orders Diptera and Haplotaxida were the most common benthic aquatic invertebrates, accounting for $76 \%$ of the total measured biomass (Supplementary Table S7). Benthic diversity index ranged from 0.25 to 1.19 (mean $=0.81$, $\mathrm{SE}=0.05$ ), which was significantly less than in nektonic communities $\left(\mathrm{t}_{21}, 0.05=7.06\right)$. We identified one model within $\triangle \mathrm{AICc}=2$ that accounted for $41 \%$ of the total AICc weight (Table 4). Chlorophyll $\alpha(+)$ was the only explanatory variable observed in the most likely model and had a significant association with benthic invertebrate diversity ( $p>0.05)$.

Nektonic biomass ranged from $0.18-2.04 \mathrm{~g} \mathrm{~m}^{-2}$ (mean $=0.64$, $\mathrm{SE}=0.09$ ) at 22 wetlands sampled during the spring of 2015 . We identified three competing models explaining nektonic biomass, which accounted for $39 \%$ of the total AICc weight (Table 4). Explanatory variables included in the most likely model were water depth $(+)$, and 
Table 3

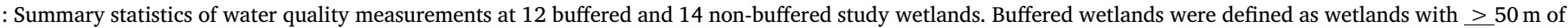

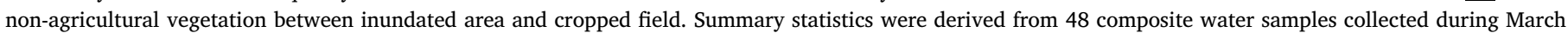
and April of 2015.

\begin{tabular}{|c|c|c|c|c|c|c|c|c|c|c|}
\hline & \multicolumn{5}{|c|}{$\underline{\text { Buffered Wetlands }(\mathrm{n}=12)}$} & \multicolumn{5}{|c|}{ Non-Buffered Wetlands $(n=14)$} \\
\hline & Mean & S.E. & Median & Min & Max & Mean & S.E. & Median & Min & Max \\
\hline \multicolumn{11}{|l|}{ Neonicotinoids } \\
\hline 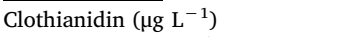 & 0.003 & 0.001 & 0.003 & $<0.002^{*}$ & 0.008 & 0.007 & 0.001 & 0.007 & $<0.002^{*}$ & 0.016 \\
\hline Imidacloprid $\left(\mu \mathrm{g} \mathrm{L}^{-1}\right)$ & 0.001 & 0.000 & $<0.002^{*}$ & $<0.002^{*}$ & 0.003 & 0.001 & 0.000 & $<0.002^{*}$ & $<0.002^{*}$ & 0.005 \\
\hline Total Neonicotinoid $\left(\mu \mathrm{g} \mathrm{L}^{-1}\right)$ & 0.004 & 0.001 & 0.004 & $<0.002^{*}$ & 0.008 & 0.007 & 0.001 & 0.007 & $<0.002^{*}$ & 0.016 \\
\hline \multicolumn{11}{|l|}{ Nutrient } \\
\hline Chlorophyll- $a\left(\mu \mathrm{g} \mathrm{L}^{-1}\right)$ & 150.60 & 29.58 & 125.08 & 47.71 & 356.28 & 236.79 & 64.92 & 179.80 & 30.81 & 803.61 \\
\hline Total Phosphorus (mg L ${ }^{-1}$ ) & 1.40 & 0.38 & 0.92 & 0.34 & 3.49 & 1.23 & 0.16 & 1.04 & 0.66 & 2.43 \\
\hline Total Nitrogen $\left(\mathrm{mg} \mathrm{L}^{-1}\right)$ & 5.68 & 1.14 & 4.24 & 1.47 & 11.77 & 5.38 & 1.03 & 4.65 & 1.79 & 14.72 \\
\hline \multicolumn{11}{|l|}{ Other Parameters } \\
\hline $\mathrm{pH}$ & 7.92 & 0.12 & 7.97 & 7.38 & 8.41 & 7.77 & 0.11 & 7.81 & 6.97 & 8.28 \\
\hline Conductivity (uS $\mathrm{cm}^{-1}$ ) & 374.08 & 101.27 & 254.44 & 105.44 & 1155.33 & 209.84 & 34.28 & 167.22 & 107.78 & 452.92 \\
\hline Total Dissolved Solids $\left(\mathrm{mg} \mathrm{L}^{-1}\right)$ & 187.06 & 50.55 & 127.67 & 51.56 & 577.08 & 104.75 & 17.08 & 83.65 & 53.78 & 226.17 \\
\hline Turbidity (NTU) & 1381.62 & 484.36 & 737.00 & 30.10 & 3912.00 & 616.90 & 292.56 & 110.85 & 18.00 & 3126.00 \\
\hline Vegetative Cover (\%) & 19.5 & 4.4 & 18.6 & 7.8 & 53.9 & 28.1 & 5.9 & 23.6 & 6.9 & 83.7 \\
\hline \multicolumn{11}{|l|}{ Aquatic Invertebrates } \\
\hline Nektonic Diversity & 1.37 & 0.09 & 1.39 & 0.77 & 1.74 & 1.45 & 0.10 & 1.46 & 0.68 & 1.87 \\
\hline Nektonic Biomass $\left(\mathrm{g} \mathrm{m}^{-1}\right)$ & 0.60 & 0.10 & 0.5 & 0.18 & 1.10 & 0.67 & 0.14 & 0.59 & 0.28 & 2.01 \\
\hline Nektonic Production $\left(\mathrm{g} \mathrm{m}^{-2} \mathrm{yr}^{-1}\right)$ & 6.14 & 1.26 & 5.16 & 1.88 & 14.72 & 7.35 & 1.19 & 6.58 & 3.51 & 18.91 \\
\hline Benthic Diversity & 0.80 & 0.09 & 0.79 & 0.24 & 1.13 & 0.81 & 0.07 & 0.83 & 0.41 & 1.19 \\
\hline Benthic Biomass $\left(\mathrm{g} \mathrm{m}^{-1}\right)$ & 1.00 & 0.37 & 0.58 & 0.19 & 4.11 & 1.09 & 0.18 & 1.14 & 0.13 & 2.07 \\
\hline Benthic Production $\left(\mathrm{g} \mathrm{m}^{-2} \mathrm{yr}^{-1}\right)$ & 4.99 & 1.85 & 3.09 & 1.18 & 20.86 & 5.10 & 0.92 & 4.41 & 1.13 & 11.88 \\
\hline
\end{tabular}

* Values below the limit of quantification $\left(<0.002 \mu \mathrm{g} \mathrm{L}^{-1}\right)$ were replaced with zero for calculation of means.

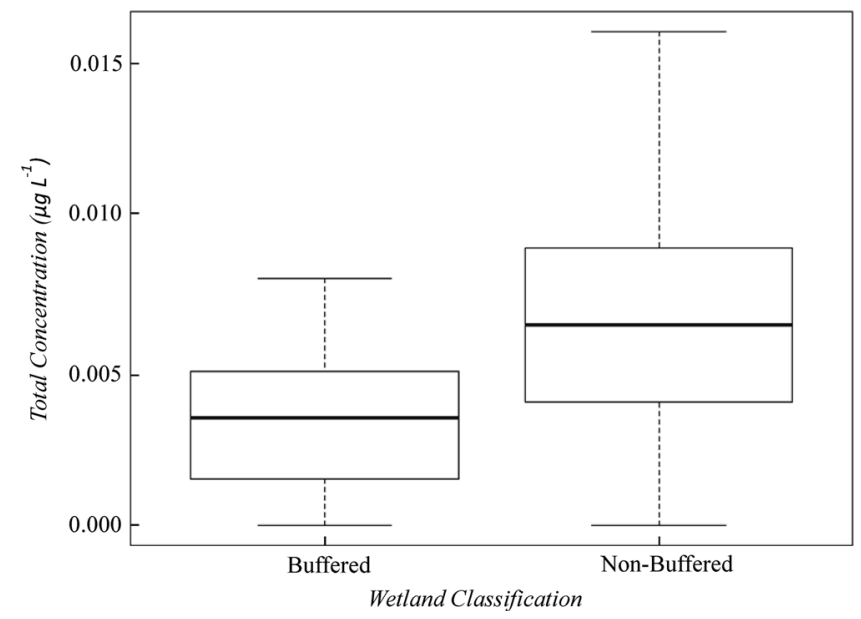

Fig. 2. Total neonicotinoid concentration is the averaged sum of clothianidin and imidacloprid measured during March and April. Buffered wetlands included units surrounded by $>50 \mathrm{~m}$ of continuous herbaceous vegetation excluding row crops, while Non-Buffered wetlands included units surrounded by $<50 \mathrm{~m}$ of continuous herbaceous vegetation. Neonicotinoid concentrations among the two treatment types were statistically greater at Non-Buffered wetlands $\left(\mathrm{W}_{26}, 0.05=42.5\right)$.

total nitrogen (-). Percent emergent vegetation $(+)$, chlorophyll $\alpha(+)$, and total neonicotinoid concentrations (-) were included in competing models. Water depth and total neonicotinoid concentration were significant when explaining nektonic invertebrate biomass averaged among competitive models using AICc weights. Benthic invertebrate biomass ranged from $0.13-4.11 \mathrm{~g} \mathrm{~m}^{-2}$ (mean $=1.05$, $\mathrm{SE}=0.19$ ), which was significantly greater than what was observed in nektonic communities $\left(t_{21}, 0.05=1.98\right)$. We identified three competing models for explaining benthic biomass, which accounted for $58 \%$ of the total AICc weight. Total dissolved solids (-) was the only explanatory variable in the most likely model, whereas conductivity (-) and pH (-) were observed in competing models. Total dissolved solids, conductivity, and $\mathrm{pH}$ were significant when explaining benthic biomass when averaged across all competing models using AICc weights.

Nektonic secondary production $\left(\mathrm{g} \mathrm{m}^{-2}\right.$ year $\left.^{-1}\right)$ ranged from 1.88 to 18.91 (mean $=6.83, \mathrm{SE}=0.85$ ) at 22 wetlands sampled in spring 2015. We identified two competing models for explaining nektonic production, which accounted for $38 \%$ of the total AICc weight (Table 4). Variables included in the most likely model were water depth $(+)$ and percentage of emergent vegetation $(+)$. Distance to nearest cropped field (-) was observed in the competing model; however, only water depth was significant in explaining production when averaged over both competing models using AICc weights. Benthic secondary production $\left(\mathrm{g} \mathrm{m}^{-2}\right.$ year $\left.^{-1}\right)$ ranged from 1.13 to 20.86 (mean $=5.05$, $\mathrm{SE}=0.95$ ), which was not statistically different from nektonic production estimates $\left(t_{21}, 0.05=1.39\right)$. We identified two competing models for explaining benthic production, which accounted for $57 \%$ of the total AICc weight. Conductivity (-) was the only explanatory variable observed in the most likely model, whereas total dissolved solids (-) was present in the only competing model. Conductivity and total dissolved solids were significant when explaining production averaged over both competing models using AICc weights.

\section{Discussion}

\subsection{Neonicotinoid concentrations and environmental standards}

We detected trace levels of neonicotinoids at $85 \%$ of wetlands sampled in the RWB during spring of 2015, prior to planting of insecticide treated seeds in the surrounding agricultural lands. Previous studies at playas in the RWB have focused on elemental contaminants, nutrient inputs, and several classes of agricultural pesticides (Foster, 2010; Belden et al., 2012; Riens et al., 2013); however, the presence and concentration of neonicotinoid insecticides were previously unknown. We predicted a relatively high detection rate for neonicotinoids given the intensity of row crop production in the region, although concentrations were lower than those reported in wetlands prior to spring planting in other regions (Main et al., 2014; USGS Pesticide National Synthesis Project, 2017). Concentrations at all 26 study wetlands sampled fell below chronic toxicity benchmarks set by the EPA. Although imidacloprid has been the most widely studied class of 
Table 4

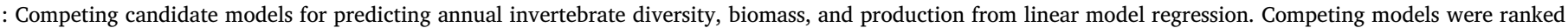

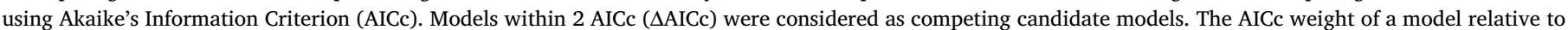

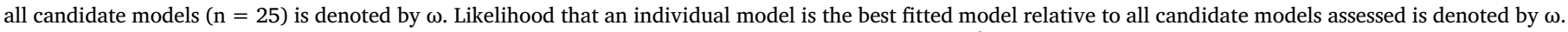

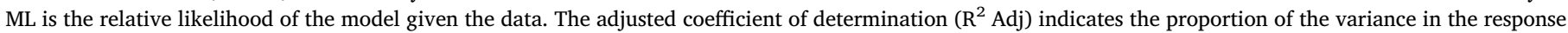
variable predicted by the explanatory variable(s).

Shannon Wiener's Diversity Index: Competing Candidate Models

\begin{tabular}{|c|c|c|c|c|c|c|c|}
\hline Community & Model & $\mathrm{K}$ & $\mathrm{AIC}_{\mathrm{c}}$ & $\Delta \mathrm{AIC}_{\mathrm{c}}$ & $\omega$ & ML & $\mathrm{R}^{2} \mathrm{Adj}$ \\
\hline Nektonic & ShannonN $\sim 1+$ Depth $^{*}-\mathrm{pH}^{*}$ & 4 & 1.50 & 0.00 & 0.35 & 1.00 & 0.54 \\
\hline Benthic & ShannonB $\sim 1+$ Chl_a* & 3 & 1.99 & 0.00 & 0.41 & 1.00 & 0.22 \\
\hline Community & Model & K & $\mathrm{AIC}_{\mathrm{c}}$ & $\Delta \mathrm{AIC}_{\mathrm{c}}$ & $\omega$ & ML & $\mathrm{R}^{2}$ Adj \\
\hline \multirow[t]{3}{*}{ Nektonic } & Biomass $\sim 1+$ Depth $^{*}-\mathrm{TN}$ & 4 & -57.49 & 0.00 & 0.17 & 1.00 & 0.40 \\
\hline & Biomass $\sim 1+$ Depth $^{*}+$ Veg & 4 & -57.14 & 0.34 & 0.14 & 0.84 & 0.39 \\
\hline & Biomass $\sim 1+$ Depth $^{*}-$ Neonic $^{*}+$ Chl_a & 5 & -55.88 & 1.61 & 0.08 & 0.45 & 0.42 \\
\hline \multirow[t]{3}{*}{ Benthic } & Biomass $\sim 1-$ TDS $^{*}$ & 3 & -2.41 & 0.00 & 0.24 & 1.00 & 0.17 \\
\hline & Biomass $\sim 1$ - Cond" & 3 & -2.40 & 0.01 & 0.24 & 1.00 & 0.17 \\
\hline & Biomass $\sim 1-\mathrm{pH}^{*}$ & 3 & -0.70 & 1.71 & 0.10 & 0.43 & 0.11 \\
\hline Community & Model & K & $\mathrm{AIC}_{\mathrm{c}}$ & $\Delta \mathrm{AIC}_{\mathrm{c}}$ & $\omega$ & ML & $\mathrm{R}^{2} \mathrm{Adj}$ \\
\hline \multirow[t]{2}{*}{ Nektonic } & Production $\sim 1+$ Depth $^{*}+$ Veg & 4 & 3.27 & 0.00 & 0.24 & 1.00 & 0.36 \\
\hline & Production $\sim 1+$ Depth $^{*}+$ DistRC & 4 & 4.35 & 1.08 & 0.14 & 0.58 & 0.33 \\
\hline \multirow[t]{2}{*}{ Benthic } & Production $\sim 1$ - Cond & 3 & 9.75 & 0.00 & 0.29 & 1.00 & 0.20 \\
\hline & Production $\sim 1-$ TDS $^{*}$ & 3 & 9.84 & 0.09 & 0.28 & 0.96 & 0.20 \\
\hline
\end{tabular}

* Parameter was a significant predictor in model ( $\mathrm{p}<0.05)$.

neonicotinoid (Cavallaro et al., 2017; Miles et al., 2017), its application in the RWB was minimal relative to clothianidin and thiamethoxam (USGS Pesticide National Synthesis Project, 2017). Accordingly, we estimated mean concentrations for imidacloprid and clothianidin as $0.001 \mu \mathrm{g} \mathrm{L}^{-1}$ and $0.005 \mu \mathrm{g} \mathrm{L}^{-1}$, respectively. Although thiamethoxam went undetected at all study sites, it is important to note that formation of clothianidin occurs as thiamethoxam degrades (Žabar et al., 2012), thus, a decrease in thiamethoxam could prompt an increase in clothianidin.

We collected water samples during March and April, which was prior to spring planting; therefore, our results likely represent chronic exposure conditions for neonicotinoid concentrations in agricultural wetlands (Schaafsma, 2015; Morrissey et al., 2015). Chronic neonicotinoid concentrations and detection frequencies reported by previous studies have been somewhat controvertible, and likely influenced by precipitation and runoff, upland crop production, and application period (Anderson et al., 2013; Hladik et al., 2014; Main et al., 2014). For instance, pre-planting detections by Main et al. (2014) included trace levels of aqueous neonicotinoid concentrations at $36 \%$ of Prairie Pothole wetlands and a mean concentration of $0.008 \mu \mathrm{g} \mathrm{L}^{-1}$ during a dry year, whereas in a wet year detection frequency and mean concentration increased to $91 \%$ and $0.052 \mu \mathrm{g} \mathrm{L}^{-1}$. Neonicotinoids have greater half-lives in soils than water, thus upland runoff can effectively recharge concentrations following adequate rainfall (Žabar et al., 2012; Hladik et al., 2014; Main et al., 2014). Precipitation was minimal in the RWB immediately prior to and during spring 2015 (Supplementary Materials: National Oceanic and Atmospheric Administration, 2017); therefore, concentrations observed in our study were likely reduced residuals from runoff accumulated during the previous summer and autumn.

\subsection{Vegetative buffers}

Upland herbaceous grasses facilitate trapping and deposition of sediment-absorbed contaminants in runoff by increasing infiltration, and sorbing dissolved phase substances to vegetation and soil surfaces in the buffer strip (Dunn et al., 2011; Satkowski et al., 2018). This relationship was evident in the RWB, as we observed significantly greater neonicotinoid concentrations at wetlands without $50 \mathrm{~m}$ vegetative buffers. Imidacloprid concentrations were similar between buffered and nonbuffered wetlands; however, clothianidin concentrations at non-buffered wetlands were approximately 2 -fold greater than wetlands with vegetative buffers. Prior studies have reported equivocal results on the utility of vegetative buffers. Dunn et al. (201 l) reported pesticides (excluding neonicotinoids) underwent a $52 \%$ reduction in concentrations for aqueous and filter phases in $10 \mathrm{~m}$ grass buffers at operational farms in Prince Edward Island. In contrast, Main et al. (2017) found no relationship between vegetative buffer width and neonicotinoid concentrations in prairie wetlands. There are a number of interacting processes influencing the utility of vegetative buffer strips, and determining effectiveness will require accurate information about a systems physical and chemical properties (Satkowski et al., 2018). In the RWB, the size of the vegetative buffer strip may be influential in mediating neonicotinoid concentrations in surface waters.

\subsubsection{Associations between neonicotinoid concentrations and invertebrate communities}

Acute and chronic toxicity thresholds for neonicotinoids vary greatly among aquatic invertebrate taxa (Morrissey et al., 2015). The timing of our study (pre-planting), in conjunction with minimal precipitation preceding spring 2015, likely limited our assessment to focusing on the effects of chronic neonicotinoid exposures. Clothianidin toxicity values for invertebrate taxa commonly observed in the RWB ranged from $2.41 \mu \mathrm{g} \mathrm{L}^{-1}$ for Chironomidae (14 day $\mathrm{LC}_{50}$; Cavallaro et al., 2017) to $>1.0 \times 10^{5} \mu \mathrm{g} \mathrm{L}{ }^{-1}$ for Daphinidae (7 day $\mathrm{LC}_{50}$; Raby et al., 2018). The maximum concentration for clothianidin observed in this study was $0.016 \mu \mathrm{g} \mathrm{L}^{-1}$. Therefore, it is unlikely that neonicotinoids observed at our study wetlands prior to spring planting were of sufficient concentration to directly influence aquatic invertebrate mortality during this time period. However, even at concentrations below the acute and chronic toxicity threshold, we still observed a negative association between nektonic invertebrate biomass and total neonicotinoid concentrations, which may be the results of sub-lethal effects to aquatic invertebrate communities. Sub-lethal effect concentrations are often reported at a fraction of $\mathrm{LC}_{50}$, and could include reduced growth, lower reproduction, immobility, reduced feeding, and delayed emergence of aquatic insect taxa (Morrissey et al., 2015; Cavallaro et al., 2018).

Secondary production accounts for the rate at which invertebrate biomass increases through growth, reproduction, and survivorship in space and time (Waters, 1977; Benke and Huryn, 2006), making it an excellent metric for assessing sub-lethal effects of contaminants. Accurately calculating secondary production for a species within a system requires intense sampling of a cohort during their entire life history 
cycle (Benke and Huryn, 2006). Given limitations in time and resources, we used an abbreviated method that relied on published $\mathrm{P}: \mathrm{B}$ values developed outside of the RWB to estimate secondary production (Eq. 1: Waters 1977; Benke, 1984; Benke and Huryn, 2006). Unfortunately, the P:B method may have been inadequate for evaluating the relationship between secondary production and neonicotinoids in our study. Habitat conditions (e.g. pH, dissolved oxygen, temperature, contaminants) vary across systems, and the physiological response to changing environments alter precise estimates of secondary production (Benke and Huryn, 2006). P:B values from this study were developed from stream invertebrate relationships, and may not be applicable for wetland communities (Waters, 1977; Krueger and Waters, 1983). Given its utility, future studies assessing the sub-lethal effects of neonicotinoids should consider measuring secondary production of specific taxa using a cohort technique (Krueger and Waters, 1983).

Field studies that simultaneously monitor aquatic invertebrate communities and neonicotinoid concentrations have been limited thus far. Cavallaro et al. (2019) also used mixed modelling in a field study to assess how neonicotinoids, in tandem with additional local parameters, influenced aquatic invertebrate emergence in Canada's Prairie Pothole Region. Similar to this study, Cavallaro et al. (2019) reported neonicotinoids as having a significant negative association with aquatic insect emergence. In addition to waterborne exposures, future field studies should also consider dietary exposure (e.g. leaf litter) when assessing impacts of neonicotinoids on detritivorous macroinvertebrates (Englert et al., 2017).

\subsubsection{Associations between non-neonicotinoid parameters and invertebrate communities}

The $\mathrm{pH}$ values reported in this study (6.97-8.41) were within an acceptable range by most water quality standards, although our mixed models indicated that as $\mathrm{pH}$ became more alkaline, nektonic diversity and benthic biomass diminished. Previous studies indicate $\mathrm{pH}$ has a strong influence on the toxicity and degradation for several water quality parameters (Kalff, 2002; Environmental Protection Agency, 2013). For example, the toxicity of total ammonia nitrogen (TAN) is strongly influenced by $\mathrm{pH}$, that is, increases in $\mathrm{pH}$ will increase the toxicity of TAN to aquatic life (Environmental Protection Agency, 2013). This study did not measure TAN, however upland row crop production, wetland cattle grazing during dry periods, and guanotrophication by spring waterfowl would all have potential for increasing TAN (Howard-Williams, 1985; Chaichana et al., 2010).

Although turbidity was not reported in the current study as being significant, additional clarification is warranted for explaining the undesired levels. Playa wetlands are believed to have been formed by the relatively high wind speeds common to the RWB (Smith 2002). High wind speeds pushing across shallow playa wetlands (mean wetland depth was $15.45 \mathrm{~cm}$ in 2015) creates waves large enough to disturb benthic substrate sediments, thus increasing turbidity (Rohweder et al., 2008). Turbidity was also greatest on buffered wetlands, which significantly less vegetative cover than non-buffered wetlands. Resuspension of sediments has been shown to be significantly greater in open water areas, unimpeded by emergent vegetation, opposed to areas protected from wind by emergent vegetation (Dieter, 1990). Riens et al. (2013) also reported highly variable turbidity values (10-20,180 NTU) during a three-year period which were in line with the measurements reported in this study. The authors acknowledge that the current study would have benefited by collecting all turbidity measurements during times of similar wind speed.

Ephemeral wetlands promote biological productivity followng recharge from snowmelt or intense precipitation events. Recolonization of aquatic invertebrate communities following wetland recharge is driven by desiccation-resistant dormant life stages, and chance of discovery by immigrant invertebrates in a terrestrial life stage (Stubbington et al., 2017). Therefore, we anticipated that wetland complexes would have greater aquatic invertebrate diversity than isolated wetlands, however the landscape parameters used to assess the importance of wetland complex were irrelevant in this study. One possible explanation is the $2.5 \mathrm{~km}$ buffer used assess wetland habitat in the surrounding landscape was inappropriate. The general consensus in the literature contends that passive dispersal is limited by increasing distance between aquatic habitats (Shurin, 2000; Cáceres and Soluk, 2002). Prior studies have found that wind and aquatic connectivity during flood events are primary dispersal vectors (Cáceres and Soluk, 2002), although anecdotal evidence also exists that supports dispersal by amphibian, birds, and terrestrial mammals (Proctor, 1964; Pennak, 1989; Shurin, 2000). Wind dispersal of aquatic invertebrates has been shown to be most effective when aquatic habitats are separated by less than $60 \mathrm{~m}$, which is far less than what was assessed in this study (Cáceres and Soluk, 2002; Vanschoenwinkel et al., 2008). Playa wetlands are positioned in closed basin systems and have no significant nexus to lotic and lentic systems, therefore dispersal by flooding would be limited to invertebrate communities in upland drainage ditches and borrow pits. Thus, movement between playa wetlands for non-terrestrial aquatic invertebrates (Anostraca, Cladocera, Dytiscidae) is likely mediated by larger animals using multiple wetland habitats.

\section{Conclusions}

Toxicity benchmarks are commonly used to estimate risk and identify potential for adverse effects of pesticide concentrations in surface waters (Anderson et al., 2013). Overall, neonicotinoid concentrations measured in this study were an order of magnitude lower than chronic toxicity benchmarks proposed by the EPA. Although results from our study are encouraging, as it relates to aquatic invertebrate availability to wetland dependent waterfowl during spring migration, it is likely we assessed wetlands during a time of year when concentrations were minimal (Hladik et al., 2014). Future research could focus on measuring post-planting concentrations at wetlands in the RWB following intense precipitation events to identify if acutely toxic concentrations occur. Subsequent sampling would also allow researchers to determine duration of acute pulses, and more accurately define intermediate concentrations in RWB wetlands. None the less, we observed a significant negative association between neonicotinoid concentrations and aquatic invertebrate biomass across all wetlands studied.

While our results support previous studies suggesting vegetative buffers improve quality of surface waters and were associated with lower concentrations of neonicotinoids, there is still an economic need to determine the precise width of an effective and efficient vegetative buffer strip. Based on current management planning recommendations (Rainwater Basin Joint Venture, 2013), we categorized based on a $50 \mathrm{~m}$ buffer, which is equivalent to 6.40 ha of economically valuable farmland surrounding a circular wetland of $10 \mathrm{ha}$. Although we observed a $50 \%$ reduction in neonicotinoid concentrations at buffered wetlands, previous studies have observed significant reductions of other pollutants using buffer strips $10 \mathrm{~m}$ in width (Dunn et al., 2011). While increasing vegetative buffer area can decrease unwanted contaminants, it might also have a negative influence on wetland water budgets by decreasing surface runoff reaching the wetlands (Castelle et al., 1994; Cariveau et al., 2011). Although beyond the scope of this study, development of predictive models based on seasonal precipitation, precipitation intensity, topography, and ratio of farmed area to inundated wetland area could be useful for determining appropriate buffer strip width at wetlands embedded in agricultural landscapes.

\section{Declaration of Competing Interest}

None. 


\section{Acknowledgements}

Primary funding for this project was provided by the Great Plains Landscape Conservation Cooperative, with additional funding provided by the Missouri Audubon Society, theRainwater Basin Joint Venture, and The Missouri Cooperative Fish and Wildlife Research Unit. The Rainwater Basin Wetland Management District of the United States Fish and Wildlife Service and the Nebraska Game and Parks Commission provided housing, vehicles, and access to management areas. The Missouri Cooperative Fish and Wildlife Research Unit is jointly sponsored by the MDC, the University of Missouri, the U.S. Fish and Wildlife Service, the U.S. Geological Survey, and the Wildlife Management Institute. Any use of trade, firm, or product names is for descriptive purposes only and does not imply endorsement by the U.S. Government.

We gratefully acknowledge R. Askren, N. Hengst, B. Woodall, Z. Haverly, K. Anderson, A. Kaemmerer, and A. Williams for their assistance with sample collection and processing. Special thanks to Randy Stutheit and Colby Compagna for guidance in the RWB, Roger Grosse for providing GIS data layers, Anson Main for his pesticide expertise, and Derek Corcoran for statistical assistance. Finally, we are indebted to the more than twenty-six private landowners who participated in this study by allowing us access to their wetlands.

\section{Appendix A. Supplementary data}

Supplementary material related to this article can be found, in the online version, at doi:https://doi.org/10.1016/j.agee.2019.106678.

\section{References}

Anderson, J.C., Dubetz, C., Palace, V.P., 2015. Neonicotinoids in the Canadian aquatic environment: a literature review on current use products with a focus on fate, exposure, and biological effects. Sci. Total Environ. 505, 409-422. https://doi.org/10. 1016/j.scitotenv.2014.09.090.

Anderson, T.A., Salice, C.J., Erickson, R.A., McMurry, S.T., Cox, S.B., Smith, L.M., 2013. Effects of land use and precipitation on pesticides and water quality in playa lakes of the southern high plains. Chemosphere 92 (1), 84-90. https://doi.org/10.1016/j. chemosphere.2013.02.054.

Beketov, M.A., Liess, M., 2008. Acute and delayed effects of the neonicotinoid insecticide thiacloprid on seven freshwater arthropods. Environ. Toxicol. Chem. 27 (2), 461-470. https://doi.org/10.1897/07-322R.1.

Beketov, M.A., Schafer, R.B., Marwitz, A., Paschke, A., Liess, M., 2008. Long-term stream invertebrate community alterations induced by the insecticide thiacloprid: effect concentrations and recovery dynamics. Sci. Total Environ. 405, 96-108.

Belden, J.B., Hanson, B.R., McMurry, S.T., Smith, L.M., Haukos, D.A., 2012. Assessment of the effects of farming and conservation programs on pesticide deposition in high plains wetlands. Environ. Sci. Technol. 46 (6), 3424-3432. https://doi.org/10.1021/ es300316q.

Benke, A.C., 1984. Secondary production of aquatic insects. In: In: Resh, V.H., Rosenberg, D.M. (Eds.), The Ecology of Aquatic Insects 10. Praeger, New York, pp. 289-322.

Benke, A.C., Huryn, A.D., 2006. Secondary production of macroinvertebrates. In: In: Hauer, F.R., Lamberti, G.A. (Eds.), Methods in Stream Ecology 2. Academic Press, San Diego, pp. 691-710.

Benke, A.C., Huryn, A.D., Smock, L.A., Wallace, J.B., 1999. Length-mass relationships for freshwater macroinvertebrates in North America with particular reference to the southeastern United States. J. North Am. Benthol. Soc. 18 (3), 308-343. https://doi. org/10.2307/1468447.

Bilotta, G.S., Brazier, R.E., 2008. Understanding the influence of suspended solids on water quality and aquatic biota. Water Res. 42 (12), 2849-2861. https://doi.org/10. 1016/j.watres.2008.03.018.

Boix, D., Batzer, D., 2016. Invertebrate assemblages and their ecological controls across the world's freshwater wetlands. In: Batzer, D., Boix, D. (Eds.), Invertebrates in Freshwater Wetlands. Springer, Switzerland, pp. 601-639. https://doi.org/10.1007/ 978-3-319-24978-0_17.

Bolen, E.G., Smith, L.M., Schramm, H.L., 1989. Playa lakes: prairie wetlands of the Southern High Plains. BioScience 39 (9), 615-623. https://doi.org/10.2307/ 1311091.

Burnham, K.P., Anderson, D.R., 2002. Model Selection and Multimodel Inference: a Practical Information-theoretic Approach. Springer Science \& Business Media, New York, USA.

Butkas, K.J., Vadeboncoeur, Y., Vander Zanden, M.J., 2011. Estimating benthic invertebrate production in lakes: a comparison of methods and scaling from individual taxa to the whole-lake level. Aquat. Sci. 73 (1), 153-169. https://doi.org/10.1007/ s00027-010-0168-1.

Cáceres, C., Soluk, D., 2002. Blowing in the Wind: a Field Test of Overland Dispersal and
Colonization by Aquatic Invertebrates. Oecologia 131 (3), 402-408. https://doi.org/ 10.1007/s00442-002-0897-5.

Cairns, J., Pratt, J.R., 1993. A history of biological monitoring using benthic macroinvertebrates. In: Rosenberg, D.M., Resh, V.H. (Eds.), Freshwater Biomonitoring and Benthic Macroinvertebrates. Chapman and Hall, New York, pp. 10-27.

Cariveau, A.B., Pavlacky, D.C., Bishop, A.A., LaGrange, T.G., 2011. Effects of surrounding land use on playa inundation following intense rainfall. Wetlands 31 (1), 65-73. https://doi.org/10.1007/s13157-010-0129-4.

Castelle, A.J., Johnson, A.W., Conolly, C., 1994. Wetland and stream buffer size requirements-a review. J. Environ. Qual. 23 (5), 878-882. https://doi.org/10.2134/ jeq1994.00472425002300050004x.

Cavallaro, M.C., Liber, K., Headley, J.V., Peru, K.M., Morrissey, C.A., 2018. Community-level and phenological responses of emerging aquatic insects exposed to 3 neonicotinoid insecticides: an in situ wetland limnocorral approach. Environ. Toxicol. Chem. 37 (9), 2401-2412. https://doi.org/10.1002/etc. 4187.

Cavallaro, M.C., Main, A.R., Liber, K., Phillips, I.D., Headley, J.V., Peru, K.M., Morrissey, C.A., 2019. Neonicotinoids and agricultural stressors collectively modify aquatic insect communities. Chemosphere 226, 945-955.

Cavallaro, M.C., Morrissey, C.A., Headley, J.V., Peru, K.M., Liber, K., 2017. Comparative chronic toxicity of imidacloprid, clothianidin, and thiamethoxam to Chironomus dilutus and estimation of toxic equivalency factors. Environ. Toxicol. Chem. 36 (2), 372-382. https://doi.org/10.1002/etc.3536.

Chaichana, R., Leah, R., Moss, B., et al., 2010. Birds as Eutrophicating Agents: A Nutrient Budget for a Small Lake in a Protected Area. Hydrobiologia 646 (1), 111-121. https://doi.org/10.1007/s10750-010-0166-2.

Clarke, K.R., Warwick, R.M., 2001. An Approach to Statistical Analysis and Interpretation. Change in Marine Communities 2. Primer-E ltd., Plymouth, UK, pp. 117-143.

Covich, A.P., Palmer, M.A., Crowl, T.A., 1999. The role of benthic invertebrate species in freshwater ecosystems: zoobenthic species influence energy flows and nutrient cycling. BioScience 49 (2), 119-127. https://doi.org/10.2307/1313537.

Crumpton, W.G., Isenhart, T.M., Mitchell, P.D., 1992. Nitrate and organic N analyses with second-derivative spectroscopy. Limnol. Oceanogr. 37 (4), 907-913. https://doi.org/ 10.4319/10.1992.37.4.0907.

Cuffney, T.F., Meador, M.R., Porter, S.D., Gurtz, M.E., 2000. Responses of physical, chemical, and biological indicators of water quality to a gradient of agricultural land use in the Yakima River Basin, Washington. In: Shabeg, S.S., Melzian, B.D., Long, E.R., Whitford, W.G., Walton, B.T. (Eds.), Monitoring Ecological Condition in the Western United States. Springer, Dordrecht, pp. 259-270. https://doi.org/10.1007/ 978-94-011-4343-1_21. Springer, Dordrecht.

Davis, C.A., Bidwell, J.R., 2008. Response of aquatic invertebrates to vegetation management and agriculture. Wetlands 28 (3), 793-805. https://doi.org/10.1672/07156.1 .

Delettre, Y.R., Morvan, N., 2000. Dispersal of adult aquatic Chironomidae (Diptera) in agricultural landscapes. Freshw. Biol. 44 (3), 399-411. https://doi.org/10.1046/j. 1365-2427.2000.00578.x.

Devries, J.H., Brook, R.W., Howerter, D.W., Anderson, M.G., 2008. Effects of spring body condition and age on reproduction in mallards (Anas platyrhynchos). Auk 125 (3), 618-628. https://doi.org/10.1525/auk.2008.07055.

Dieter, C.D., 1990. The importance of emergent vegetation in reducing sediment resuspension in wetlands. J. Freshw. Ecol. 5 (4), 467-473. https://doi.org/10.1080/ 02705060.1990 .9665263

Dormann, C.F., Elith, J., Bacher, S., Buchmann, C., Carl, G., Carré, G., Marquéz, J.R.G., Gruber, B., Lafourcade, B., Leitão, P.J., Münkemüller, T., 2013. Collinearity: a review of methods to deal with it and a simulation study evaluating their performance. Ecography 36 (1), 27-46. https://doi.org/10.1111/j.1600-0587.2012.07348.x.

Duffy, W.G., LaBar, D.J., 1994. Aquatic invertebrate production in southeastern USA wetlands during winter and spring. Wetlands 14 (2), 88-97. https://doi.org/10. 1007/BF03160625.

Dunn, A.M., Julien, G., Ernst, W.R., Cook, A., Doe, K.G., Jackman, P.M., 2011. Evaluation of buffer zone effectiveness in mitigating the risks associated with agricultural runoff in Prince Edward Island. Sci. Total Environ. 409 (5), 868-882. https://doi.org/10. 1016/j.scitotenv.2010.11.01.

Eaton, A.D., Clesceri, L.S., Greenberg, A., Federation, W.E., 1995. Standard Methods for the Examination of Water and Waste, 19th edition. American Public Health Association, New York, USA.

Englert, D., Zubrod, J.P., Link, M., Mertins, S., Schulz, R., Bundschuh, M., 2017. Does waterborne exposure explain effects caused by neonicotinoid-contaminated plant material in aquatic systems? Environ. Sci. Technol. 51 (10), 5793-5802.

Environmental Protection Act, 2005. Watercourse and Wetland Protection Regulations, Revised Statutes of Prince Edward Island. 1988, Cap E -9.

Environmental Protection Agency, 2013. Aquatic Life Ambient Water Quality Criteria For Ammonia - Freshwater 2013. Environmental Protection Agency, Washington, District of Columbia, USA.

Environmental Protection Agency, 2019. Aquatic Life Benchmarks for Pesticide Registration. https://www.epa.gov/pesticide-science-and-assessing-pesticide-risks/ aquatic-life-benchmarks-pesticide-registration.

Euliss, N.H., Mushet, D.M., 1999. Influence of agriculture on aquatic invertebrate communities of temporary wetlands in the prairie pothole region of North Dakota, USA Wetlands 19 (3), 578-583. https://doi.org/10.1007/BF03161695.

Euliss, N.H., Wrubleski, D.A., Mushet, D.M., 1999. Wetlands of the prairie pothole region: invertebrate species composition, ecology, and management. In: Batzer, D.P., Radar, R.B., Wissinger, S.A. (Eds.), Invertebrates in Freshwater Wetlands of North America: Ecology and Management. John Wiley and Sons, USA, pp. 471-514.

Evelsizer, V., Skopec, M., 2018. Pesticides, including neonicotinoids, in drained wetlands of Iowa's prairie pothole region. Wetlands 38 (2), 221-232. https://doi.org/10.1007/ 
s13157-016-0796-x.

Foster, S.E., 2010. Temporal and Spatial Variations of Ions, Isotopes and Agricultural Contaminants in Surface Waters and Groundwater of Nebraska's Rainwater Basin Wetland Region. Thesis. University of Nebraska, USA.

Gelman, A., 2008. Scaling regression inputs by dividing by two standard deviations. Stat. Med. 27 (15), 2865-2873. https://doi.org/10.1002/sim.3107.

Gleason, R.A., Euliss, N.H., Hubbard, D.E., Duffy, W.G., 2003. Effects of sediment load on emergence of aquatic invertebrates and plants from wetland soil egg and seed banks. Wetlands 23 (1), 26-34. https://doi.org/10.1672/02775212(2003) 023[0026:EOSLOE]2.0.CO;2.

Gledhill, D.G., James, P., Davies, D.H., 2008. Pond density as a determinant of aquatic species richness in an urban landscape. Landsc. Ecol. 23 (10), 1219-1230. https:// doi.org/10.1007/s10980-008-9292-x.

Goulson, D., 2013. An overview of the environmental risks posed by neonicotinoid insecticides. J. Appl. Ecol. 50 (4), 977-987. https://doi.org/10.1111/1365-2664. 12111.

Hallmann, C.A., Foppen, R.P., van Turnhout, C.A., de Kroon, H., Jongejans, E., 2014 Declines in insectivorous birds are associated with high neonicotinoid concentrations. Nature 511 (7509), 341-343. https://doi.org/10.1038/nature13531.

Hansen, M.C., Loveland, T.R., 2012. A review of large area monitoring of land cover change using Landsat data. Remote Sens. Environ. 122, 66-74. https://doi.org/10. 1016/j.rse.2011.08.024.

Hladik, M.L., Kolpin, D.W., Kuivila, K.M., 2014. Widespread occurrence of neonicotinoid insecticides in streams in a high corn and soybean producing region, U.SA. Environ. Pollution 193, 189-196. https://doi.org/10.1016/j.envpol.2014.06.033.

Howard-Williams, C., 1985. Cycling and Retention of Nitrogen and Phosphorus in Wetlands: A Theoretical and Applied Perspective. Freshwater Biology 15 (4), 391-431. https://doi.org/10.1111/j.1365-2427.1985.tb00212.x.

Jeschke, P., Nauen, R., Schindler, M., Elbert, A., 2010. Overview of the status and global strategy for neonicotinoids. J. Agric. Food Chem. 59 (7), 2897-2908. https://doi.org/ 10.1021/jf101303g.

Johnson, L.A., 2011. Occurrence, Function, and Conservation of Playa Wetlands: The Key to Biodiversity of the Southern Great Plains. PhD Dissertation. Dept. of Natural Resources Management, Texas Tech University, Lubbock, TX, USA.

Kalff, J., 2002. Limnology. Inland Water System. Prentice Hall, New Jersey.

Klemm, D.J., 1990. Macroinvertebrate Field and Laboratory Methods for Evaluating the Biological Integrity of Surface Waters. U.S. Environmental Protection Agency, Environmental Research Laboratory, Corvallis, Oregon, USA.

Krueger, C.C., Waters, T.F., 1983. Annual production of macroinvertebrates in three streams of different water quality. Ecology 64 (4), 840-850. https://doi.org/10. $2307 / 1937207$.

LaGrange, T.G., 2005. Guide to Nebraska's Wetlands and Their Conservation Needs. Nebraska Game and Parks Commission, Lincoln, USA.

Main, A.R., Fehr, J., Liber, K., Headley, J.V., Peru, K.M., Morrissey, C.A., 2017. Reduction of neonicotinoid insecticide residues in Prairie wetlands by common wetland plants. Sci. Total Environ. 579, 1193-1202. https://doi.org/10.1016/j.scitotenv.2016.11. 102.

Main, A.R., Headley, J.V., Peru, K.M., Michel, N.L., Cessna, A.J., Morrissey, C.A., 2014 Widespread use and frequent detection of neonicotinoid insecticides in wetlands of Canada's Prairie Pothole Region. PLoS One 9 (3). https://doi.org/10.1371/journal. pone.0092821. p.e92821.

Main, A.R., Webb, E.B., Goyne, K.W., Mengel, D., 2018. Neonicotinoid insecticides negatively affect performance measures of non-target terrestrial arthropods: a meta-analysis. Ecol. Appl. 28 (5), 1232-1244. https://doi.org/10.1002/eap.1723.

Mazerolle, M.J., 2016. AICcmodavg: Model Selection and Multimodel Inference Based on (Q)AIC(c). Version 2.1-0.

Miles, J.C., Hua, J., Sepulveda, M.S., Krupke, C.H., Hoverman, J.T., 2017. Effects of clothianidin on aquatic communities: evaluating the impacts of lethal and sublethal exposure to neonicotinoids. PLoS One 13 (3), e0194634.

McMurtrey, M.S., Craig, R., Schildman, G., 1972. Nebraska Wetland Survey, Habitat Work Plan K-71. Nebraska Game and Parks Commission, Lincoln, Nebraska, USA

Morrissey, C.A., Mineau, P., Devries, J.H., Sanchez-Bayo, F., Liess, M., Cavallaro, M.C., Liber, K., 2015. Neonicotinoid contamination of global surface waters and associated risk to aquatic invertebrates: a review. Environ. Int. 74, 291-303. https://doi.org/10. 1016/j.envint.2014.10.024.

Murkin, H.R., Kadlec, J.A., 1986. Responses by benthic macroinvertebrates to prolonged flooding of marsh habitat. Can. J. Zool. 64 (1), 65-72. https://doi.org/10.1139/z86010.

Murkin, H.R., Kaminski, R.M., Titman, R.D., 1982. Responses by dabbling ducks and aquatic invertebrates to an experimentally manipulated cattail marsh. Can. J. Zool. 60 (10), 2324-2332. https://doi.org/10.1139/z82-299.

National Oceanic and Atmospheric Administration, 2017. National Weather Service Internet Services Team. Monthly Precipitation for Reno, Nevada. http://www.wrh. noaa.gov/rev/hydrology/monthly_precip.php.

Oksanen, J., Guillaume Blanchet, F., Kindt, R., Legendre, P., 2017. Vegan: Community Ecology Package. R Package Version 2.3-5.

Pennak, R.W., 1989. Fresh-water Invertebrates of the United States, third edition. John Wiley \& Sons, Inc., New York, NY, USA.

Pereira, A.S., Cerejeira, M.J., Daam, M.A., 2017. Ecological risk assessment of imidacloprid applied to experimental rice fields: accurateness of the RICEWQ model and effects of ecosystem structure. Ecotoxicol. Environ. Saf. 142, 431-440.

Proctor, V.W., 1964. Viability of crustacean eggs recovered from ducks. Ecology 45 (3), 656-658. https://doi.org/10.2307/1936124.

Quinn, G.P., Keough, M.J., 2002. Experimental Design and Data Analysis for Biologists Cambridge University Press.

Raby, M., Zhao, X., Hao, C., Poirier, D.G., Sibley, P.K., 2018. Relative chronic sensitivity of neonicotinoid insecticides to Ceriodaphnia dubia and Daphnia magna. Ecotoxicol. Environ. Saf. 163, 238-244. https://doi.org/10.1016/j.ecoenv.2018.07.086.

Rainwater Basin Joint Venture, 2013. The Rainwater Basin Joint Venture Implementation Plan. Rainwater Basin Joint Venture, Grand Island, Nebraska, USA.

Raines, R.R., Gilbert, M.C., Gersib, R.A., Rosier, W.S., Dinan, K.F., 1990. Regulatory Planning for Nebraska's Rainwater Basin Wetlands. Prepared for the Rainwater Basin Advanced Identification Study. US Environmental Protection Agency, Region VII, Kansas City, Kansas US Army Corps of Engineers, Omaha, Nebraska, USA.

Rexrode, M., Barrett, M., Ellis, J., Gabe, P., Vaughan, A., Felkel, J., Melendez, J., 2003. EFED Risk Assessment for the Seed Treatment of Clothianidin 600FS on Corn and Canola. United States Environmental Protection Agency, pp. 20.

Richards, S.A., 2005. Testing ecological theory using the information-theoretic approach: examples and cautionary results. Ecology 86 (10), 2805-2814. https://doi.org/10. 1890/05-0074.

Riens, J.R., Schwarz, M.S., Mustafa, F., Hoback, W.W., 2013. Aquatic macroinvertebrate communities and water quality at buffered and non-buffered wetland sites on federal waterfowl production areas in the Rainwater Basin, Nebraska. Wetlands 33 (6), 1025-1036. https://doi.org/10.1007/s13157-013-0460-7.

Rohweder, J.J., Rogala, J.T., Johnson, B.L., Anderson, D., Clark, S., Chamberlin, F., Runyon, K., 2008. Application of Wind Fetch and Wave Models for Habitat Rehabilitation and Enhancement Projects. United States Geological Survey No. 20081200 .

Sánchez-Bayo, F., Goka, K., Hayasaka, D., 2016. Contamination of the aquatic environment with neonicotinoids and its implication for ecosystems. Front. Environ. Sci. 4 (71). https://doi.org/10.3389/fenvs.2016.00071.

Sartory, D.P., Grobbelaar, J.U., 1984. Extraction of chlorophyll a from freshwater phytoplankton for spectrophotometric analysis. Hydrobiologia 114 (3), 177-187. https://doi.org/10.1007/BF00031869.

Satkowski, L.E., Goyne, K.W., Anderson, S.H., Lerch, R.N., Webb, E.B., Snow, D.D., 2018 Imidacloprid sorption and transport in cropland, grass buffer, and riparian buffer soils. Vadose Zone J. 17 (170139). https://doi.org/10.2136/vzj2017.07.0139.

Schaafsma, A., Limay-Rios, V., Baute, T., Smith, J., Xue, Y., 2015. Neonicotinoid in secticide residues in surface water and soil associated with commercial maize (corn) fields in southwestern Ontario. PLoS One 10 (2). https://doi.org/10.1371/journal. pone.0118139. p.e0118139.

Schepker, T.J., 2017. Evaluating the Relationship Between Local Food Availability and Wetland Landscape Structure in Determining Dabbling Duck Habitat Use During Spring. migration. Thesis. University of Missouri-Columbia, USA.

Schepker, T.J., LaGrange, T., Webb, E.B., 2019. Are waterfowl food resources limited during spring migration? A bioenergetic assessment of playas in Nebraska's Rainwater Basin. Wetlands 39 (1), 173-184. https://doi.org/10.1007/s13157-0181047-0.

Sherfy, M.H., Kirkpatrick, R.L., Richkus, K.D., 2000. Benthos core sampling and chironomid vertical distribution: implications for assessing shorebird food availability. Wildl. Soc. Bull. 28 (1), 124-130.

Shurin, J., 2000. Dispersal Limitation, Invasion Resistance, and the Structure of Pond Zooplankton Communities. Ecology 81 (11), 3074-3086. https://doi.org/10.1890/ 0012-9658(2000)081[3074:DLIRAT]2.0.CO;2.

Smit, C.E., Posthuma-Doodeman, J.A.M., van Vlaardingen, P.L.A., de Jong, F.M.W., 2015. Ecotoxicity of imidacloprid to aquatic organisms: derivation of water quality standards for peak and long-term exposure. Hum. Ecol. Risk Assess. 21 (6), 1608-1630. https://doi.org/10.1080/10807039.2014.964071.

Smith, L.M., 2003. Playas of the Great Plains. University of Texas Press, Austin, USA.

Song, M.Y., Stark, J.D., Brown, J.J., 1997. Comparative toxicity of four insecticides, including imidacloprid and tebufenozide, to four aquatic arthropods. Environ. Toxicol. Chem. 16 (12), 2494-2500. https://doi.org/10.1002/etc.5620161209.

Sparks, T.C., 2013. Insecticide discovery: an evaluation and analysis. Pestic. Biochem. Physiol. 107 (1), 8-17. https://doi.org/10.1016/j.pestbp.2013.05.012.

Spieles, D.J., Mitsch, W.J., 2000. Macroinvertebrate community structure in high-and low-nutrient constructed wetlands. Wetlands 20 (4), 716-729. https://doi.org/10. 1672/0277-5212(2000)020[0716:MCSIHA]2.0.CO;2.

Stagliano, D.M., Whiles, M.R., 2002. Macroinvertebrate production and trophic structure in a tallgrass prairie headwater stream. J. North Am. Benthol. Soc. 21 (1), 97-113. https://doi.org/10.2307/1468303.

Stephens, P.A., Buskirk, S.W., Hayward, G.D., Del Rio, C.M., 2005. Information theory and hypothesis testing: a call for pluralism. J. Appl. Ecol. 42 (1), 4-12. https://doi org/10.1111/j.1365-2664.2005.01002.x.

Stubbington, R., Bogan, M., Bonada, N., Bolton, A., Datry, T., Leigh, C., Vander Vorste, R., et al., 2017. The Biota of Intermittent Rivers and Ephemeral Streams: Aquatic Invertebrates. Intermittent Rivers and Ephemeral Streams. Academic Press, pp. 217-243.

Swanson, G.A., 1983. Benthic sampling for waterfowl foods in emergent vegetation. J. Wildl. Manage. 47 (3), 821-823. https://doi.org/10.2307/3808618.

De Szalay, F.A., Resh, V.H., 2000. Factors influencing macroinvertebrate colonization of seasonal wetlands: responses to emergent plant cover. Freshw. Biol. 45 (3), 295-308. https://doi.org/10.1111/j.1365-2427.2000.00623.x.

Tapp, J.L., Webb, E.B., 2015. Aquatic invertebrate food base for waterbirds at wetland reserve program easements in the lower Mississippi Alluvial Valley. Wetlands 35 (1), 183-192. https://doi.org/10.1007/s13157-014-0613-3.

Tidwell, P.R., Webb, E.B., Vrtiska, M.P., Bishop, A.A., 2013. Diets and food selection of female mallards and blue-winged teal during spring migration. J. Fish Wildl. Manag. 4, 63-74.

United States Geological Survey, 2017. Pesticide National Synthesis Project. Available:http://water.usgs.gov/nawqa/pnsp/usage/maps/compound_listing.php (Accessed 2017 January 25).

Van Dijk, T.C., Van Staalduinen, M.A., Van der Sluijs, J.P., 2013. Macro-invertebrate 
decline in surface water polluted with imidacloprid. PLoS One 8 (5). https://doi.org/ 10.1371/journal.pone.0062374. p.e62374.

Vanschoenwinkel, B., Gielen, S., Vandewaerde, H., Seaman, M., Brendonck, L., et al., 2008. Relative Importance of Different Dispersal Vectors for Small Aquatic Invertebrates in a Rock Pool Metacommunity. Ecography 31 (5), 567-577. https:// doi.org/10.1111/j.0906-7590.2008.05442.x.

Wallace, J.B., Webster, J.R., 1996. The role of macroinvertebrates in stream ecosystem function. Annu. Rev. Entomol. 41 (1), 115-139. https://doi.org/10.1146/annurev. en.41.010196.000555.

Waters, T.F., 1977. Secondary Production in Inland Waters, in: Advances in Ecological Research 10. Academic Press, London, pp. 91-164. https://doi.org/10.1016/S00652504(08)60235-4.

Webb, E.B., Smith, L.M., Vrtiska, M.P., Lagrange, T.G., 2010. Effects of local and landscape variables on wetland bird habitat use during migration through the Rainwater Basin. J. Wildl. Manage. 74 (1), 109-119.

Whiting, D.P., Whiles, M.R., Stone, M.L., 2011. Patterns of macroinvertebrate production, trophic structure, and energy flow along a tallgrass prairie stream continuum. Limnol. Oceanogr. 56 (3), 887-898. https://doi.org/10.4319/lo.2011.56.3.0887.

Yeo, I.K., Johnson, R.A., 2000. A new family of power transformations to improve normality or symmetry. Biometrika 87 (4), 954-959. https://doi.org/10.1093/biomet/ 87.4.954.

Žabar, R., Komel, T., Fabjan, J., Kralj, M.B., Trebše, P., 2012. Photocatalytic degradation with immobilised $\mathrm{TiO} 2$ of three selected neonicotinoid insecticides: imidacloprid, thiamethoxam and clothianidin. Chemosphere 89 (3), 293-301. https://doi.org/10. 1016/j.chemosphere.2012.04.039. 